\title{
PENGARUH PENGGUNAAN VIRGIN COCONUT OIL TERHADAP GATAL DI KULIT PADA PASIEN GAGAL GINJAL KRONIK DENGAN HEMODIALISA
}

\author{
${ }^{1}$ Hotman Adi Syaputra, ${ }^{2}$ Febrina Angraini Simamora, ${ }^{3}$ Mei Adelina Harahap \\ ${ }^{1}$ Mahasiswa Program Studi Keperawatan Program Sarjana Universitas Aufa Royhan Kota Padangsidimpuan \\ ${ }^{2,3^{3}}$ Dosen Program Studi Keperawatan Program Sarjana Universitas Aufa Royhan Kota Padangsidimpuan \\ Hotman.adi18@gmail.com
}

\begin{abstract}
Abstrak
Gagal ginjal Kronik merupakan gangguan fungsi ginjal dalam melakukan penyaringan tubuh. Penumpukan ureum ini akan menyebabkan rasa gatal yang dirasakan dikulit pasien gagal ginjal kronik dengan hemodialisa. Salah satu cara untuk mengatasi masalah gatal dikulit adalah dengan menerapkan penggunaan Virgin Coconut Oil yang dioleskan ke kulit untuk mengatasi masalah gatal. Tujuan dari penelitian ini adalah untuk mengetahui pengaruh Virgin Coconut Oil terhadap gatal dikulit pasien gagal ginjal kronik dengan Hemodialisa. Populasi dalam penelitian ini adalah seluruh pasien gagal ginjal kronik yang sedang menjalani terapi Hemodialisa yang berjumlah 44 orang. Sampel pada penelitian ini ditentukan dengan perhitungan rumus slovin yaitu 15 responden. Desain penelitian menggunakan Quasi Eksperimen yaitu dengan rancangan pre test - post test dengan jumlah sampel berjumlah 15 responden. Uji Statistik yang digunakan adalah uji Wilcoxon. Hasil penelitian menunjukkan bahwa ada perbedaan yang signifikan terhadap penurunan rasa gatal yang dirasakan responden setelah intervensi dengan $P$-Value 0,001 hasil tersebut $<0,05$. Hasil penelitian ini dapat dijadikan sebagai terapi alternatif yang mengalami masalah kulit seperti rasa gatal dengan menggunakan Virgin Coconut Oil .
\end{abstract}

Kata kunci : Virgin Coconut oil, Hemodialisa, Gatal, Gagal Ginjal Kronik

\begin{abstract}
Chronic kidney desease is a disruption in the function of the kidneys in filtering the body. This urea buildup will cause an itchy feeling that is felt on the skin of patients with chronic renal failure with hemodialysis.. One way to overcome the problem of itching on the skin is to apply the use of Virgin Coconut Oil which is applied to the skin to overcome the problem of itching. The purpose of this study was to determine the effect of Virgin Coconut Oil on the itchy skin of chronic kidney failure patients with Hemodialysis. The population in this study were all patients with chronic kidney failure who were undergoing Hemodialysis therapy, amounting to 44 people. The sample in this study was determined by the calculation of the Slovin formula of 15 respondents. The study design used was Quasi Experiment with a pre-post test design with a total sample of 15 respondents. The statistical test used is the Wilcoxon test. The results showed that there was a significant difference in the decrease in itching felt by respondents after the intervention with $P$ value 0.001, the results were $<0.05$. The results of this study can be used as an alternative therapy that experiences skin problems such as itching by using Virgin Coconut Oil.
\end{abstract}

Keyword : Virgin Coconut oil, Hemodialysis, Itching, Chronic Kidney Disease 


\section{Pendahuluan}

Gagal ginjal kronik merupakan suatu penyakit kronis yang progresifitasnya dapat bertambah buruk karena potensial komplikasi yang terjadi. Komplikasi yang biasa terjadi yaitu hipertensi, anemia, perikarditis, hiperkalemia, bahkan sampai kematian. Gagal ginjal kronik merupakan penyakit yang mengancam jiwa dan angka kejadiannya di masyarakat terus meningkat (Santoso, 2009).

The National Kidney Foundation 2015, terjadi peningkatan pasien yang melakukan hemodialisis, pada tahun 2012 terdapat 2.497 pasien sedangkan pada tahun berikutnya terdapat 2.518 pasien di Singapura. Setiap tahun, ada kasus baru kira-kira 30/1.000.000 penduduk masuk dalam penyakit ginjal tahap akhir.

Berdasarkan Riset Kesehatan Dasar atau Riskesdas 2018, prevalensi penyakit ginjal kronis di Indonesia sebesar 3,3\% pada tahun 2018, data ini menunjukkan adanya peningkatan dari tahun 2016 yang hanya berada pada 1,8 (Riskesdas, 2018).

Sedangkan menurut data Dinas kesehatan Provinsi Sumatera Utara pada tahun 2014, di Provinsi Sumatera Utara, penderita gagal ginjal kronik berjumlah 2608 jiwa dengan jumlah penderita terbanyak pada usia diatas 55 tahun.

Pasien yang mengalami gagal ginjal kronik akan menjalani hemodialisa jangka panjang, hemodialisa (HD) adalah suatu prosedur dimana darah dikeluarkan dari tubuh penderita dan beredar dalam sebuah mesin di luar tubuh yang disebut dialiser. Frekuensi tindakan Hemodialisa bervariasi tergantung banyaknya fungsi ginjal yang tersisa, ratarata penderita menjalani tiga kali dalam seminggu, sedangkan lama pelaksanaan hemodialisa paling sedikit tiga sampai empat jam tiap sekali tindakan terapi (Brunner, Suddath, 2002).

Pruritus uremik yang juga disebut pruritus terkait penyakit gagal ginjal kronis tetap merupakan masalah yang sering dijumpai dan terkadang menyiksa pada pasien dengan stadium lanjut atau stadium akhir penyakit ginjal. Banyak upaya yang telah dilakukan untuk meringankan gejala yang menyebalkan ini yang terkenan pruritus, namun keberhasilannya yang terbatas (Putu, 2018).

Minyak kelapa (Virgin Coconut Oil atau VCO) adalah minyak kelapa murni yang dibuat tanpa pemanasan atau dengan pemanasan minimal. Penggunaan minyak kelapa murni sebagai bahan perawatan kulit dan rambut telah dilakukan oleh masyarakat Indonesia secara turun temurun. Pemanfaatan Virgin Coconut Oil dapat dimanfaatkan dalam bidang kesehatan (Subroto, 2012).

\section{Metode Penelitian}

Penelitian ini menggunakan jenis penelitian kuantitatif dengan desain Quasyexperimental design dengan menggunakan bentuk rancangan one group pretest-postest. Pretest-postest penelitian dilakukan dengan cara memberikan penilaian awal (pretest) terlebih dahulu sebelum diberikan perlakuan (intervensi), kemudian diberikan intervensi dengan cara melakukan pendidikan kesehatan setelah itu dilakukan posttest. (Notoatmodjo, 2010).

Populasi dalam penelitian ini adalah seluruh klien Gagal ginjal kronik yang menjalani terapi Hemodialisa di rumah sakit umum daerah Kota Padangsidimpuan dengan berdasarkan survey pendahuluan di jumlah pasien yang menjalani terapi hemodialisa adalah 42 pasien pada tanggal 7 November 2019 
Peneliti menggunakan tehnik Konsekutif Sampling selama dua bulan yaitu pada bulan Juni-Juli 2020, mencari penderita yang memenuhi kriteria inklusi dan eksklusi sampai memenuhi kriteria yang dibutuhkan oleh peneliti. Pembagian sampel berdasarkan tujuan tertentu yang tidak menyimpang dari kriteria yang sudah ditetapkan oleh peneliti. Penentuan sampel dilakukan dengan menggunakan perhitungan Slovin sehingga di dapatkan jumlah sampel sebanyak 15 responden.

\section{Hasil}

Tabel 1. Distribusi Frekuensi dan Persentase Karakteristik responden berdasarkan Jenis Kelamin, Umur dan Pendidikan.

\begin{tabular}{lll}
\hline Karakteristik & Frekuensi & persentase (\%) \\
\hline Jenis kelamin & & \\
Laki-Laki & 10 & $66,7 \%$ \\
Perempuan & 5 & $33,3 \%$ \\
\hline Total & $\mathbf{1 5}$ & $\mathbf{1 0 0 , 0 \%}$ \\
\hline Umur & & $40 \%$ \\
$40-49$ tahun & 6 & $60 \%$ \\
$50-59$ tahun & 9 & \\
& & $\mathbf{1 0 0 , 0 \%}$ \\
Total & $\mathbf{1 5}$ & $20 \%$ \\
\hline Pendidikan & 3 & $6,7 \%$ \\
SD & 1 & $60 \%$ \\
SMP & 9 & $13,3 \%$ \\
SMA & 2 & $\mathbf{1 0 0 , 0 \%}$ \\
SARJANA & $\mathbf{1 5}$ & \\
\hline Total & & \\
\hline
\end{tabular}

Berdasarkan tabel frekuensi diatas didapatkan hasil dari 15 responden jumlah responden yang berjenis kelamin laki-laki adalah mayoritas yaitu sebanyak 10 responden atau $(66,7 \%)$, dan minoritas adalah jenis kelamin perempuan dengan jumlah 5 responden atau $(33,3 \%)$.

Berdasarkan tabel frekuensi diatas didapatkan hasil dari 15 responden jumlah responden yang berusia 50-59 tahun adalah mayoritas dengan jumlah 9 responden atau (60\%), jumlah responden dengan usia 40-49 tahun adalah minoritas yaitu dengan jumlah 6 responden atau $(40 \%)$.

Dari tabel frekuensi diatas didapatkan hasil sebanyak 15 responden jumlah responden yang berpendidikan terakhir SMA adalah mayoritas yaitu sebanyak 9 responden atau $(60 \%)$, dan responden dengan pendidikan terakhir SMP adalah minoritas yaitu sebanyak 1 responden atau $(6,7 \%)$.

Tabel 2. Hasil Distribusi Frekuensi Pre Test dan Post Test Gatal Di Kulit Pasien Gagal Ginjal Kronik Dengan Hemodialisa

\begin{tabular}{lllclll}
\hline Variabel & Mean & Median & SD & Min & Max & N \\
\hline Sebelum & 6,87 & 7,00 &, 990 & 5 & 8 & 15 \\
Sesudah & 3,27 & 6,00 &, 961 & 2 & 5 & 15 \\
\hline
\end{tabular}


Berdasarkan tabel distribusi frekuensi menunjukkan bahwa rata-rata nilai gatal yang dirasakan dikulit pasien gagal ginjal kronik dengan hemodialisa dalam tahapan pre test pada penelitian ini adalah 6,87 dengan nilai minimum 5 dan nilai maximum adalah 8 dengan jumlah sampel sebanyak 15 responden. Nilai rata-rata gatal yang dirasakan dikulit pasien gagal ginjal kronik dengan hemodialisa dalam tahapan pos test pada penelitian ini adalah 3,27 dengan nilai minimum 2 dan nilai maximum adalah 5 dengan jumlah sampel sebanyak 15 responden.

Tabel 3. Hasil uji Normalitas Pengaruh Penggunaan Virgin Coconut Oil Terhadap Gatal Di Kulit Pasien Gagal Ginjal Kronik Dengan Hemodialisa.

\begin{tabular}{ccccccc}
\hline & \multicolumn{3}{c}{ Kolmogorov-Smirnov $^{\text {a }}$} & \multicolumn{3}{c}{ Shapiro-Wilk } \\
\hline Pre & Statistic & Df & Sig. & Statistic & Df & Sig \\
Post &, 209 & 15 & 0,79 &, 861 & 15 &, 025 \\
\hline
\end{tabular}

Berdasarkan hasil uji normalitas diatas diperoleh nilai Sig dari Shapiro-wilk untuk hasil Pre test adalah 0,025, dan untuk post test didapatkan hasil 0,037. Nilai tersebut menunjukkan hasil $>0,05$ sehinnga hasil yang diperoleh adalah data tersebut tidak berdistribusi normal sehingga digunakan uji alternatif yaitu uji Wilcoxon.

Tabel 4. Hasil Uji Statistik Menggunakan Uji Wilcoxon

\begin{tabular}{llll} 
& Median (Min-Maks) & Selisih Mean & Nilai Sig \\
\hline $\begin{array}{l}\text { Derajat Gatal dikulit } \\
\text { sebelum perlakuan }\end{array}$ & $7,00(5-8)$ & 3,6 & 0.001 \\
$\begin{array}{l}\text { Derajat Gatal dikulit } \\
\text { sesudah perlakuan }\end{array}$ & $6,00(2-5)$ & & \\
\hline
\end{tabular}

\section{Pembahasan}

Berdasarkan penelitian yang dilakukan saniya (2017) yang berjudul faktor yang berhubungan dengan kejadian penyakit ginjal kronik pada penderita hipertensi di indonesia menjelaskan terdapat hubungan yang bermakna antara usia (kategori 45-54 tahun dan 55 - 64 tahun), ia juga menjelaskan setelah usia 30tahun ginjal akan mengalami atrofi dan ketebalan kortek ginjal akan berkurang $20 \%$ setiap dekade.

Dari hasil penelitian bahwa ada pengaruh usia terhadap kejadian gagal ginjal kronik, peneliti juga menemukan hasil yang sama terbukti Dari hasil penelitian yang dilakukan terhadap 15 responden, mayoritas responden adalah yang berusia 50-59 dengan jumlah 9 responden atau (60\%) dan untuk jumlah responden dengan usia 40-49 tahun adalah responden minoritas dengan jumlah 6 responden atau (40\%).

Berdasarkan penelitian yang dilakukan oleh saniya (2017) menjelaskan bahwa responden yang berjenis kelamin laki-laki beresiko 1,783 kali lebih besar terkena penyakit ginjal kronik dibandingkan dengan responden yang berjenis kelamin perempuan. Hal ini sama dengan penelitian yang dilakukan oleh Pranandari dan Woro ynang menyatakan bahwa jenis jelamin secara statistik memiliki hubungan yang bermakna dengan kejadian penyakit ginjal kronik pada pasien hemodialysis. Secara klinis laki-laki 
mengalami resiko terkena penyakit ginjal kronik 2 kali lebih besar dibandingkan perempuan.

Hasil penelitian yang dilakukan terhadap 15 responden juga mendapatkan hal yang sama yaitu jumlah responden yang berjenis kelamin laki-laki merupakan responden mayoritas yaitu sebanyak 10 responden atau $(66,7 \%)$, dan responden minoritas adalah jenis kelamin perempuan dengan jumlah 5 responden atau $(33,3 \%)$. Hal ini menunjukkan bahwa laki-laki lebih rentan terkena gagal ginjal.

Berdasarkan penelitian Cahyati et al (2015) yang menggunakan Virgin Coconut Oil terhadap ruam popok pada bayi yang dilakukan selama lima hari, Virgin Coconut Oil dioleskan dua kali sehari pada pagi dan sore hari setelah mandi. Menunjukkan hasil adanya perbedaan yang signifikan antara ruam popok setelah diberikan intervensi Virgin Coconut Oil dengan sebelum diberikan Intervensi Virgin Coconut Oil.

Menurut Nurainah Fajriati dalam penelitian yang berjudul Pengaruh pemberian terapi VCO (Virgin coconut oil) terhadap pruritus pada klien gagal ginjal kronik dengan hemodialisis di RSIJ Cempaka putih tahun 2018 menyatakan tidak terdapat perbedaan yang signifikan antara derajat pruritus sebelum pada kelompok kontrol dan kelompok perlakuan dengan p-value 0,832 , sedangkan setelah intervensi terdapat perbedaan yang signifikan antara kelompok kontrol dan kelompok perlakuan dengan p-value 0,000. Sehingga dapat disimpulkan bahwa ada pengaruh pemberian terapi VCO (Virgin coconut oil) terhadap pruritus setelah diberikan intervensi terapi VCO selama tujuh hari.

Beberapa definisi menurut peneliti sebelumnya disimpulkan bahwa ada pengaruh penggunan virgin coconut oil terhadap masalah kulit yang dialami oleh pasien gagal ginjal kronik dengan hemodialisa dan penelitian yang dilakukan oleh peneliti di RSUD umum Kota padangsidimpuan dengan jumlah responden sebanyak 15 orang juga mendapatkan hasil yang sama yaitu hasil uji statistik Wilcoxon dengan p-value 0,001 nilai tersebut $<0,05$ yang artinya bahwa ada pengaruh penggunaan virgin coconut oil mendapatkan hasil yang sama yaitu pendidikan minoritas adalah SMP yaitu sebanyak 1 responden atau $(6,7 \%)$.

\section{Kesimpulan}

Hasil analisa Pengaruh Penggunaan Virgin Coconut Oil Terhadap Gatal Di Kulit Pasien Gagal Ginjal Kronik Dengan Hemodialisa dengan menggunakan uji Wilcoxon diperoleh hasil $\mathrm{P}=0,001$ nilai tersebut $>0.05$ sehingga dapat disimpulkan bahwa ada Pengaruh Penggunaan Virgin Coconut Oil Terhadap Gatal Di Kulit Pasien Gagal Ginjal Kronik Dengan Hemodialisa.

Karakteristik responden yang berjenis kelamin laki-laki lebih berpotensi mengalami gagal ginjal kronik dibandingkan responden perempuan dengan hasil uji karakteristik responden adalah sebanyak $66,7 \%$ atau sebanyak 10 responden.

Berdasarkan uji Normalitas derajat gatal yang dirasakan responden sebelum diberikan virgin coconut oil adalah dengan nilai rata-rata 6,87 artinya derajat gatal yang dirasakan responden masih tinggi.

Berdasarkan uji Normalitas derajat gatal yang dirasakan responden sesudah diberikan virgin coconut oil terdapat penurunan nilai rata-rata 6,87 menjadi 3,27 artinya ada penurunan derajat gatal yang signifikan 


\section{Referensi}

Brunner \& Suddarth, 2002, Buku Ajar Keperawatan Medikal Bedah, alih bahasa: Waluyo Agung., Yasmin Asih., Juli., Kuncara., I.made karyasa, EGC, Jakarta.

Cahyati, D., Antarini, I., Arie K. (2013). Pengaruh Virgin Coconut Oil Terhadap Ruam Popok Pada Bayi. Jurnal Keperawatan Sriwijaya, 2(1), 2355-5459. https://ejournal.unsri.ac.id/index.php/jk_sriwijaya/article/viewFile/2332/1195

National Kidney Foundation. 2015. About Chronic Kidney Disease. Diakses dari: https://www.kidney.org/kidneydisease/aboutckd. Diunduh pada 18 November 2019.

Putu intan darmawanti (2018). Pengaruh kombinasi stimulus kutaneus dan Virgin coconut oil terhadap kelembaban kulit,kenyamanan dan kualitas tidur pada pasien Gagal ginjal kronik.

Riskesdas. (2013). Laporan Nasional. Badan Penelitian Dan Pengembangan Kesehatan. Departemen Kesehatan RI

Riskesdas. (2018). Laporan Nasional. Badan Penelitian Dan Pengembangan Kesehatan. Departemen Kesehatan RI

Saniya dkk (2017) Faktor Yang Berhubungan Dengan Kejadian Penyakit Ginjal Kronik Pada Penderita Hipertensi Di Indonesia

Santoso, D. (2009). 60 Menit Menuju Ginjal Sehat. Surabaya: Jaring Pena

Subroto, Ahkam. (2012). VCO Dosis Tepat Taklukan Penyakit. Jakarta: Swadaya 